\title{
THE ETHOS OF DEMOCRACY
}

\author{
ANNELIEN DE DIJN \\ Department of Political Science, University of Amsterdam \\ E-mail: a.m.r.dedijn@uva.nl
}

James Kloppenberg's Toward Democracy is a monumental achievement. To start with, Kloppenberg's breadth and depth of knowledge are awe-inspiring. He begins his story in the late sixteenth century, at the height of the religious wars in France, with the philosopher Michel de Montaigne, who rejected democracy because he did not believe ordinary people were capable of the self-restraint it required. Kloppenberg ends his narrative three hundred years later, with the poet Walt Whitman, lamenting the rise of unbridled individualism in the post-Civil War United States. Even though much attention is devoted to intellectual developments in northern America-Kloppenberg is, after all, specialized in American history - his book places these in a much broader context, highlighting how both in the colonial period and beyond Americans participated in transatlantic "communities of discourse" (2). In that sense, Toward Democracy contributes towards the recent transatlantic turn in American historiography.

But Kloppenberg's book is, of course, first and foremost a contribution to the history of democracy and in particular to the history of the idea of democracy. When looked at from that perspective, Kloppenberg's approach immediately reveals itself as strikingly original. Toward Democracy is certainly not the first broad-brush intellectual history of democracy. In the past decade alone, books by John Dunn, John Keane and Paul Cartledge all have dealt with the same subject. ${ }^{1}$ But these scholars either tend to focus on conceptual history in the strict sense of the word (how was the word "democracy" understood throughout the centuries?) or they are primarily interested in debates about how to institutionalize democracy. Kloppenberg's book is much more wide-ranging. It is a history of "democratic thought" in the broadest sense of the word, zooming 
in not just on institutional debates, but also on the discussions about democracy's ethical preconditions.

Indeed, one of Kloppenberg's main goals is to show that, from the early seventeenth century to the late nineteenth, democracy was understood as an ethical as much as a political ideal. Throughout the early modern period and the nineteenth century, he argues, political thinkers on both sides of the Atlantic argued that a genuine democracy could not exist in a vacuum. In order to be something other than the tyranny of the majority, popular self-government required a commitment to a broader, ethical agenda, most notably to deliberation, value pluralism, and reciprocity (the habit of "treating all persons with respect and weighing well their aspirations and their ways of looking at the world" (10)). In turn, these values were based on the Judeo-Christian heritage shared by most individuals in the period under discussion in this book. Understanding the history of democracy therefore means, as Kloppenberg argues, taking into account also the religious ideals that animated many democratic reformers.

This approach helps to explain why Kloppenberg ends his narrative in the late nineteenth century. From a more traditional perspective, this choice of terminus might seem surprising. After all, there is an argument to be made that for much of humanity, the story of democracy only properly began in the late nineteenth and early twentieth centuries. Even in countries that were historically in the advance guard of the democratic movement, like the United States, genuinely universal suffrage was only achieved in the course of the twentieth century, after long and hard-fought ideological battles. Kloppenberg recognizes the importance of these battles, and his book pays frequent homage to the women and men who fought them in order to make their political regimes more inclusive. Nevertheless, he believes that the twentieth-century triumph of democracy in institutional terms - the conquest of universal suffrage-masks the failure of democracy in another sense of the word-as an ethical ideal. This pessimistic view is captured well in the title of the third and final part of Kloppenberg's book, "Failure in Success."

Kloppenberg makes a number of different suggestions to explain why that happened. On the one hand, he indicates that the rise of a more individualistic and egoistic outlook on social life, exemplified by new doctrines such as social Darwinism, undermined the ethical dimensions of democratic culture (11, 707). At the same time, the disappearance of a shared Judeo-Christian outlook contributed to the decline of the democratic temperament. "Perhaps because many people today have lost confidence in the universality of the religious ideas that originally infused democratic discourse," Kloppenberg writes, "we tend to overlook the democratic ethic of reciprocity taken for granted by earlier generations, which leaves us with a flattened appreciation of the meaning and potential of democratic life" (11). 
Toward Democracy is, in other words, not just a history of democratic thought-even though it certainly was Kloppenberg's primary intent to write such a history. It can also be seen as an intervention in contemporary debates about what democracy is, or rather about what democracy can and should be. More specifically, by focusing on pre-twentieth-century democratic thought, Kloppenberg aims to recover an understanding of democracy that has now become lost, or at least obscured from view. As he puts it, "This study resurrects the importance of ethical and religious ideas in democratic discourse because our contemporary scholarly and popular emphasis on economic efficiency and self-interested political behavior blinds us to the equally important role played by other considerations in the history of democracy" (15).

This exercise in recovery is very important to Kloppenberg, because he believes that these earlier democratic theorists were onto something important. In his view, they were right in thinking that democracy cannot be simply understood as a set of institutions and procedures. The fact that we have lost sight of this broader, ethical dimension of popular self-government goes a long way to explaining, Kloppenberg suggests, why democracy continues, at least in some important ways, to fail us, despite its institutional triumph in many parts of the world.

This is stimulating stuff. It is also a very timely argument. Indeed, Toward Democracy could not have appeared at a better moment. In the wake of the highly divisive and shockingly uncivil American presidential campaign-in which one candidate repeatedly promised to "lock up" his opponent if he won-it is hard not to agree with Kloppenberg that we urgently need to shore up the ethical foundations of our democracies. Equally persuasive is Kloppenberg's suggestion that, at least in this respect, there is still much we can learn from earlier democratic thinkers, no matter how limited their understanding of who should be included in the demos. When reading Kloppenberg's history, it is hard not to be infected by his palpable sense of regret for statesmen like Thomas Jefferson, who, after crushing his opponent in the painfully divisive election of 1800 , called for unity and promised to respect the rights of minorities. ("All too will bear in mind this sacred principle," as Jefferson put it, "that though the will of the majority is in all cases to prevail, that will to be rightful must be reasonable; that the minority possess their equal rights, which equal law must protect, and to violate would be oppression" (587).)

That does not mean, however, that Toward Democracy is wholly free from warts. In particular, this reviewer is more than puzzled by the fact that Kloppenberg puts so much emphasis on what he describes as a "shared Judeo-Christian outlook" as an essential source of democratic thought. Is it really "historically undeniable," as Kloppenberg claims, that the Hebrew Bible and Christian Scripture were the "source of the animating ideals of modern democratic movements in the Atlantic world"? Christian faith, as Kloppenberg of course knows perfectly well, 
and as he repeatedly recognizes in his book, was just as capable of inspiring murderous zealotry as humility and agape_-just like other firmly held beliefs, be they religious in nature or not, have proved themselves capable of producing the kind of fanaticism incompatible with democracy.

Rather than the Christian heritage an sich, the experience of the religious wars of the sixteenth century seems a more likely wellspring of principles of toleration and mutual forbearance. Their horrific violence inspired the kind of philosophical skepticism defended by Michel de Montaigne, a man who, as Kloppenberg himself points out in one of the more powerful passages of his book, embodied the ethic of reciprocity in the most violent of times. (In 1576, we learn, Montaigne had a bronze medallion struck with two inscriptions that neatly captured the essence of this ethic. One side read "Je m'abstiens," or "I restrain myself." The other side asked a question equally out of favor in a time of religious fervor: "Que sçais-je?” or "What do I know?" (23).)

Kloppenberg's insistence on the importance of the religious underpinnings of democratic thought also leads him to some debatable decisions (again, in the view of this reviewer) in the selection of his sources. That becomes particularly clear when we look at his account of the Enlightenment contribution to the development of democratic thought in Part II of Toward Democracy. Throughout, Kloppenberg focuses on what he calls the "Moderate Enlightenment"; that is, those enlightened thinkers who "shared respect for the value of religious faith and had little sympathy with materialist philosophy" - a perspective he ascribes to thinkers like Charles-Louis de Montesquieu, Jean-Jacques Rousseau, Adam Smith and most of the American revolutionaries (573). By contrast, Kloppenberg downplays the contribution of the "more radical partisans of the Enlightenment"; that is, those who "tended to value reason over emotion, scientific truth over superstitious folklore" - a category that includes not just the admittedly undemocratic Physiocrats, but also philosophes like the marquis de Condorcet, whose work still inspires contemporary democratic theorists. Their contribution to democratic thought was limited, Kloppenberg argues, because "they proved more inclined to trust sympathetic enlightened despots than to put their faith in the judgment of custom-bound ordinary people" (192). Moreover, their vociferous championing of change during the French Revolution would eventually provoke a backlash among traditionalists, which in turn led the Revolution down the path of the Terror, thus harming democracy's standing in the view of many moderates.

By making these claims, Kloppenberg defends a position exactly the opposite of the controversial thesis put forward by Jonathan Israel in the Radical 
Enlightenment and successive volumes. ${ }^{2}$ In contrast to Kloppenberg, Israel has claimed that modern democracy and accompanying values such as equality were invented by the most radical, atheistic philosophes, while he has dismissed the deist philosophes as defenders of the political status quo. Israel has been much criticized for assuming that there is an automatic and unproblematic connection between religious and political radicalness; and it could be argued that Kloppenberg's account suffers from the same problem, albeit in reverse. ${ }^{3}$ Instead, it seems much more fruitful to recognize that, to the extent that certain enlighteners were more politically radical than others, this was a response to the changing political context in France and other countries rather than an outgrowth of their religious beliefs (or the lack thereof).

Some of Kloppenberg's own preferred thinkers, moreover, were far more skeptical about the compatibility between Christianity and popular selfgovernment than Kloppenberg seems willing to admit. Jean-Jacques Rousseau is a case in point. Kloppenberg devotes much attention to Rousseau, whom he reevaluates (rightly so, in the perspective of this reviewer) as the eighteenth century's most important democratic thinker. In Kloppenberg's account, Rousseau emerges as a visionary thinker who emphasized more eloquently than any other philosophe the ethic of reciprocity and the value of autonomy, rather being a misguided and anachronistic defender of direct democracy, as he is often portrayed. Kloppenberg also makes mincemeat of the stubborn myth that Rousseau "caused" or "influenced" the Jacobins and the Terror they unleashed, by showing how selectively they read his texts. By contrast, the Franco-Swiss thinker did have a considerable influence, as Kloppenberg shows, on John Adams, surely one of the most moderate and least radical of the American Founding Fathers-a claim that throws a new and surprising light on both Rousseau and Adams.

All of this is very good; but Kloppenberg also ignores some important aspects of Rousseau's thought. Notably, he papers over the fact that Rousseau himself believed that Christianity, as a proselytic religion, tended to work contrary to ethic of democracy. Yet this point was so important to Rousseau that he devoted

2 Jonathan Israel, Radical Enlightenment: Philosophy and the Making of Modernity (Oxford, 2001); Israel, Enlightenment Contested: Philosophy, Modernity, and the Emancipation of Man, 1670-1752 (Oxford, 2006); Israel, Democratic Enlightenment: Philosophy, Revolution, and Human Rights, 1750-1790 (New York, 2011). For an overview of the broader debate see Annelien de Dijn, “The Politics of Enlightenment: From Peter Gay to Jonathan Israel”, Historical Journal 55/3 (2012) 785-805. Kloppenberg explicitly distinguishes his position from that of Israel's in the extended footnotes to the book, which are available online at http://scholar.harvard.edu/files/jameskloppenberg/files/toward_democracy_extended_ notes.pdf; see 109-10.

3 For this criticism of Israel see, for instance, Anthony La Vopa, 'A New Intellectual History? Jonathan Israel's Enlightenment', Historical Journal 52/3 (2009) 717-38. 
a whole chapter of the Social Contract to it — the notorious final chapter on "civil religion." In this oft-misunderstood chapter, Rousseau was remarkably negative about the political effects of Christianity, declaring it a religion wholly unsuitable for republican self-government. ("Christianity preaches nothing but servitude and dependence. Its spirit is too favorable to tyranny for tyranny not always to profit from it.”) ${ }^{4}$ But his main argument against Christianity was that it bred intolerance. Christ had created a "spiritual kingdom," which, by separating the theological realm from the political system, had fatally divided the state, and brought about eternal dissensions in Christian nations. "It is impossible to live at peace with those we regard as damned," Rousseau wrote, "to love them would be to hate God who punishes them: we positively must either reclaim or torment them."

My point in bringing up these remarks is not to argue that Rousseau was right; rather, it is to suggest that Kloppenberg's insistence on the religious and in particular Christian underpinnings of democratic political culture was less than self-evident to some of the thinkers he himself values the most.

Nevertheless, these remarks do not substantially detract from Kloppenberg's remarkable achievement. Toward Democracy amply succeeds in its main goal: demonstrating that, historically speaking, debates about democracy have never been limited to purely institutional questions. Is representative government or direct democracy to be preferred? Who should be enfranchised and where to draw the line between demos and outsiders? These have long been, and remain, crucial questions for any democratic thinker. But less tangible issues-how a majority can be persuaded to take the interests and values of minorities into account, how to instill the necessary virtues of humility and forbearance and patience that allow for peaceful power transitions - these were all understood to be just as important by earlier generations of democratic thinkers. It is a lesson we forget at our own peril.

4 Jean-Jaques Rousseau, The Social Contract and Other Later Political Writings, ed. and trans. Victor Gourevitch (Cambridge, 1997), 149.

$5 \quad$ Ibid., 151. 